\title{
PELATIHAN BUDIDAYA CACING SUTERA UNTUK PENINGKATAN EKONOMI MASYARAKAT DESA FAJAR BARU, LAMPUNG SELATAN
}

\author{
Rindu Rika Gamayuni ${ }^{1 *}$, Fajar Gustiawaty Dewi ${ }^{2}$, Fitra $^{3}$, Kiagus Andi ${ }^{4}$ \\ Jurusan Akuntansi Universitas Lampung, Bandar Lampung \\ Jl. Prof. Sumantri Brojonegoro No.1 Bandar Lampung 35145 \\ Penulis Korespodensi: rindu.gamayuni@yahoo.com
}

\begin{abstract}
Abstrak
Kegiatan Pengabdian Kepada Masyarakat ini ditujukan pada kelompok Tani Fajar III yang berada di Dusun III A, Desa Fajar Baru, Kecamatan Jati Agung, Kabupaten Lampung Selatan. Warga kelompok tani ini mayoritas memiliki pekerjaan sebagai petani penggarap padi di sawah. Usaha budidaya cacing sutera ini memiliki banyak keuntungan antaralain bisa menjadi penghasilan tambahan bagi warga yang sangat menguntungkan karena tingkat kebutuhan cacing sutera yang tinggi sebagai pakan untuk pembenihan ikan. Cacing sutera juga bisa untuk pakan ternak lainnya seperti ayam dan bebek, atau bahan pembuat kosmetik.

Usaha sampingan ini sangat tepat bagi petani karena keuntungan yang cukup tinggi dengan modal operasional yang kecil. Namun petani saat ini belum memiliki pengetahuan dan keterampilan yang cukup untuk budidaya cacing sutera. Target yang ingin dicapai adalah peningkatan pengetahuan dan keterampilan petani dalam budidaya cacing sutera, dapat memperoleh keuntungan maksimal dengan harga jual yang tepat, serta dapat memasarkannya dengan maksimal. Diharapkan dusun ini menjadi pusat budidaya dan penghasil cacing sutera yang bisa memenuhi kebutuhan di Lampung dan daerah lainnya di Indonesia.

Solusi dan metode untuk menyelesaikan permasalahan tersebut antaralain dengan memberikan pengetahuan dan pelatihan bagaimana cara budidaya cacing sutera yang tepat dan menguntungkan, cara menentukan harga jual, menghitung modal dan keuntungan, serta bagaimana pemasarannya. Disamping itu juga dilakukan praktek langsung dan pendampingan budidaya cacing sutera mulai dari tahap pembuatan media ternak, pembibitan cacing sutera, dan dievaluasi sampai dengan proses panen cacing sutera sehingga siap dipasarkan. Budidaya cacing sutera ini diharapkan dapat sebagai tambahan penghasilan warga, dan diharapkan banyak warga yang tertarik melakukan usaha ini sehingga dapat meningkatkan perekonomian desa.
\end{abstract}

Kata Kunci: budidaya cacing sutera, pakan bibit ikan, harga jual, pemasaran

\section{Latar Belakang}

Kegiatan pengabdian kepada masyarakat ini ditujukan bagi Kelompok Tani Fajar III, yang beralamat di J1. RA.Basyid, Dusun III A, Desa Fajar Baru, Kecamatan Jati Agung, Kabupaten Lampung Selatan. Warga kelompok tani ini mayoritas memiliki pekerjaan sebagai petani penggarap padi di sawah. Usaha budidaya cacing sutera ini bisa menjadi penghasilan tambahan bagi warga yang cukup menguntungkan karena tingkat kebutuhan cacing sutera yang tinggi sebagai pakan untuk pembenihan ikan. Selama ini pengusaha pembenihan ikan mendapat pasokan pakan dari Pulau Jawa, karena di Lampung masih sangat terbatas. Selain itu, harga jual cacing sutera juga cukup tinggi, dengan modal operasional yang relative sedikit sehingga budidaya cacing sutera ini menjanjikan keutungan yang cukup besar. Media dan sarana yang digunakan dalam budidaya ini relatif mudah didapat, yaitu lumpur sawah, dan kolam terpal yang bisa ditempatkan di pekarangan warga. Pakan cacing juga gratis, karena cukup menggunakan limbah organik cacing bisa tumbuh dengan baik.

Kebutuhan cacing sutera (Tubifex $s p$ ) sebagai salah satu pakan alami untuk budi daya perikanan (terutama saat pembenihan ikan), dari waktu ke waktu terus memperlihatkan peningkatan. Kenaikan itu bisa terjadi, karena cacing sutera menjadi salah satu pakan alami yang digunakan para pembudi 
daya di seluruh Indonesia, khususnya kegiatan budi daya air tawar. Keuntungan dari budi daya cacing sutera adalah tidak memerlukan luasan lahan yang besar, namun cukup dengan memanfaatkan pekarangan rumah. Selain itu, juga tidak memerlukan waktu yang lama ( 2 bulan sudah bisa panen), sehingga pengembalian investasinya bisa lebih singkat dan perputaran uang juga lebih cepat. Cacing ini meiliki nilai gizi yang tinggi sehingga dapat memenuhi kebutuhan nutrisi bagi pertumbuhan benih ikan. Cacing sutera juga dapat digunakan sebagai bahan baku obat dan kosmetik, bahan baku pakan ternak ayam, bebek dan ikan, sehingga petani bisa menghemat biaya pakan ternak, karena bisa memproduksi sendiri.

Kegiatan pengabdian ini merupakan implementasi / penerapan dari hasil penelitian sebelumnya yaitu penelitian Gamayuni (2017) yang berjudul Penguatan teknologi informasi akuntansi manajemen desa dan implementasi undang-undang No. 6 / 2014 tentang Desa untuk meningkatkan pengelolaan keuangan desa di kabupaten / kota di Lampung. Hasil penelitian ini memberikan bukti empiris bahwa implementasi UU No. 6 / tahun 2004 tentang Pengelolaan Keuangan Desa terbukti dapat meningkatkan pengelolaan keuangan desa. Begitupula penelitian Fahri (2017) bahwa pelaksanaan kebijakan dana desa terhadap manajemen keuangan desa dapat meningkatkan efektivitas program pembangunan desa. Warga desa harus dapat menggali potensi yang dimiliki desa untuk meningkatkan kemakmuran warga desanya.

Berdasarkan hasil survey, wawancara, dan diskusi dengan Kelompok Tani, permasalahan yang terjadi berdasarkan kondisi saat ini adalah: a. Kurangnya pengetahuan dan keterampilan budidaya cacing sutera, b. Masih terbatasnya peralatan dan sarana yang dibutuhkan untuk usaha bubidaya cacing sutera, c. Bagaimana menentukan harga jual yang tepat, d. Pemasaran cacing sutera sebagai pakan usaha pembibitan ikan. Tujuan kegiatan pengabdian kepada masyarakat ini adalah untuk menerapkan dan menyebarluaskan hasil-hasil penelitian/kajian kepada masyarakat sebagai bagian dari upaya untuk memberdayakan dan meningkatkan kesejahteraan masyarakat, melalui pemberian pelatihan dan penyuluhan tentang cara budidaya cacing sutera. Manfaat kegiatan ini adalah untuk meningkatkan perekonomian warga melalui usaha budidaya dan penjualan cacing sutera. Semakin banyak petani yang membudidayakan cacing sutera semakin baik karena Dusun ini bisa menjadi pusat penghasil cacing sutera yang bisa memenuhi kebutuhan cacing sutera di Lampung dan bisa diekspor ke Pulau lainnya di Indonesia yang masih banyak membutuhkan.

\section{Bahan dan Metode}

Kegiatan pengabdian kepada masyarakat di Desa Sungai Langka ini dilakukan dengan metode dan tahapan sebagai berikut:

a. Analisis situasi, untuk mengetahui permasalahan yang terjadi dan kebutuhan warga desa khususnya Kelompok Tani dalam usahanya untuk meningkatan perekonomian melalui usah budidaya cacing sutera sebagai usaha sampingan warga untuk menambah pemasukan keluarga.

b. Memberikan penyuluhan dan pelatihan kepada Kelompok Tani Desa Fajar Baru. Pada tahap ini dilakukan penyuluhan dan pelatihan manfaat dan keuntungan budidaya cacing sutera, serta cara budidaya ternak cacing sutera yang baik, bagaimanan menentukan harga jual dan pemasarannya.

c. Selanjutnyan akan dilakukan pendampingan selama 3 bulan ke depan, dan evaluasi apakah Kelompok Tani sudah dapat memahami dan melaksanakan pengetahuan yang diberikan sampai dengan berhasil panen cacing sutera.

Kegiatan dihadiri oleh Ketua kelompok tani beserta anggotanya, bertempat di salah satu pekarangan warga Desa Fajar Baru. Berikut adalah deskriptif pelaksanaan kegiatan pengabdian:

Table 1. Deskripsi kegiatan

\begin{tabular}{|c|c|c|c|}
\hline No. & Kegiatan & Pelaksanaan & Prosedur Kerja \\
\hline \multirow[t]{9}{*}{1} & \multirow{9}{*}{$\begin{array}{l}\text { Menyiapkan/ } \\
\text { membangun } \\
\text { kolam terpal } \\
\text { untuk media } \\
\text { cacing sutera } \\
\text { di pekarangan } \\
\text { salah satu } \\
\text { warga } \\
\text { kelompok } \\
\text { tani }\end{array}$} & \multirow{9}{*}{$\begin{array}{l}1 \text { bulan } \\
\text { sebelum } \\
\text { kegiatan }\end{array}$} & \multirow{7}{*}{$\begin{array}{l}\text { Membuat } \\
\text { kolam terpal } \\
\text { dan sarana } \\
\text { prasarana yang } \\
\text { akan digunakan } \\
\text { sebagai tempat } \\
\text { berkembang }\end{array}$} \\
\hline & & & \\
\hline & & & \\
\hline & & & \\
\hline & & & \\
\hline & & & \\
\hline & & & \\
\hline & & & biak cacing \\
\hline & & & sutera \\
\hline 2 & Pembukaan & Hari ke-1 & Panitia \\
\hline & dan pre test. & Pukul 8.00- & memberikan \\
\hline & & 9.00 & $\begin{array}{l}\text { kuesioner } \\
\text { sebagai pre tes }\end{array}$ \\
\hline
\end{tabular}




\begin{tabular}{|c|c|c|c|}
\hline & & & $\begin{array}{l}\text { untuk } \\
\text { mengetahui } \\
\text { pengetahuan } \\
\text { peserta sebelum } \\
\text { diberikan } \\
\text { pelatihan. }\end{array}$ \\
\hline 3 & $\begin{array}{l}\text { Penyuluhan } \\
\text { tentang } \\
\text { manfaat } \\
\text { budidaya } \\
\text { cacing sutera }\end{array}$ & $\begin{array}{l}\text { Hari ke-1 } \\
\text { Pukul 9.00- } \\
10.00\end{array}$ & $\begin{array}{l}\text { Pemaparan } \\
\text { pengetahuan } \\
\text { dengan cara } \\
\text { presentasi } \\
\text { dengan } \\
\text { menggunakan } \\
\text { slide projector, } \\
\text { memberikan } \\
\text { video yang } \\
\text { menginspirasi }\end{array}$ \\
\hline 4 & $\begin{array}{l}\text { Pelatihan cara } \\
\text { atau tahapan } \\
\text { budidaya } \\
\text { cacing sutera }\end{array}$ & $\begin{array}{l}\text { Hari ke-1 } \\
\text { Pukul } \\
10.00- \\
12.00\end{array}$ & $\begin{array}{l}\text { Pelatihan cara } \\
\text { budidaya } \\
\text { cacing sutera } \\
\text { menggunakan } \\
\text { slide projector, } \\
\text { menayangkan } \\
\text { video yang } \\
\text { menjelskan } \\
\text { tahapan } \\
\text { beternak cacing } \\
\text { sutera dampai } \\
\text { dengan panen. }\end{array}$ \\
\hline 5 & $\begin{array}{l}\text { Penyuluhan } \\
\text { tentang } \\
\text { penentuan } \\
\text { harga jual } \\
\text { yang tepat, } \\
\text { penghitungan } \\
\text { modal dan } \\
\text { keutungan. }\end{array}$ & $\begin{array}{l}\text { Hari ke-1 } \\
\text { Pukul } \\
13.00- \\
15.00\end{array}$ & $\begin{array}{l}\text { Pemberian } \\
\text { pengetahuan } \\
\text { penentuan } \\
\text { harga jual yang } \\
\text { tepat, } \\
\text { penghitungan } \\
\text { modal dan } \\
\text { keutungan. }\end{array}$ \\
\hline 6 & $\begin{array}{l}\text { Penyuluhan } \\
\text { tentang } \\
\text { pemasaran } \\
\text { cacing sutera }\end{array}$ & $\begin{array}{l}\text { Hari ke-1 } \\
\text { Pukul } \\
15.00- \\
16.00\end{array}$ & $\begin{array}{l}\text { Pemberian } \\
\text { pengetahuan } \\
\text { tentang seluk } \\
\text { beluk } \\
\text { pemasaran } \\
\text { cacing sutera }\end{array}$ \\
\hline 7 & $\begin{array}{l}\text { Evaluasi post } \\
\text { test }\end{array}$ & $\begin{array}{l}\text { Hari ke-1 } \\
\text { Pukul } \\
16.00- \\
17.00\end{array}$ & $\begin{array}{l}\text { Evaluasi untuk } \\
\text { mengetahui } \\
\text { sejauhmana } \\
\text { peningkatan } \\
\text { pemahaman } \\
\text { petani setelah } \\
\text { memperoleh } \\
\text { penyuluhan dan } \\
\text { pelatihan } \\
\text { budidaya } \\
\text { cacing sutera. }\end{array}$ \\
\hline
\end{tabular}

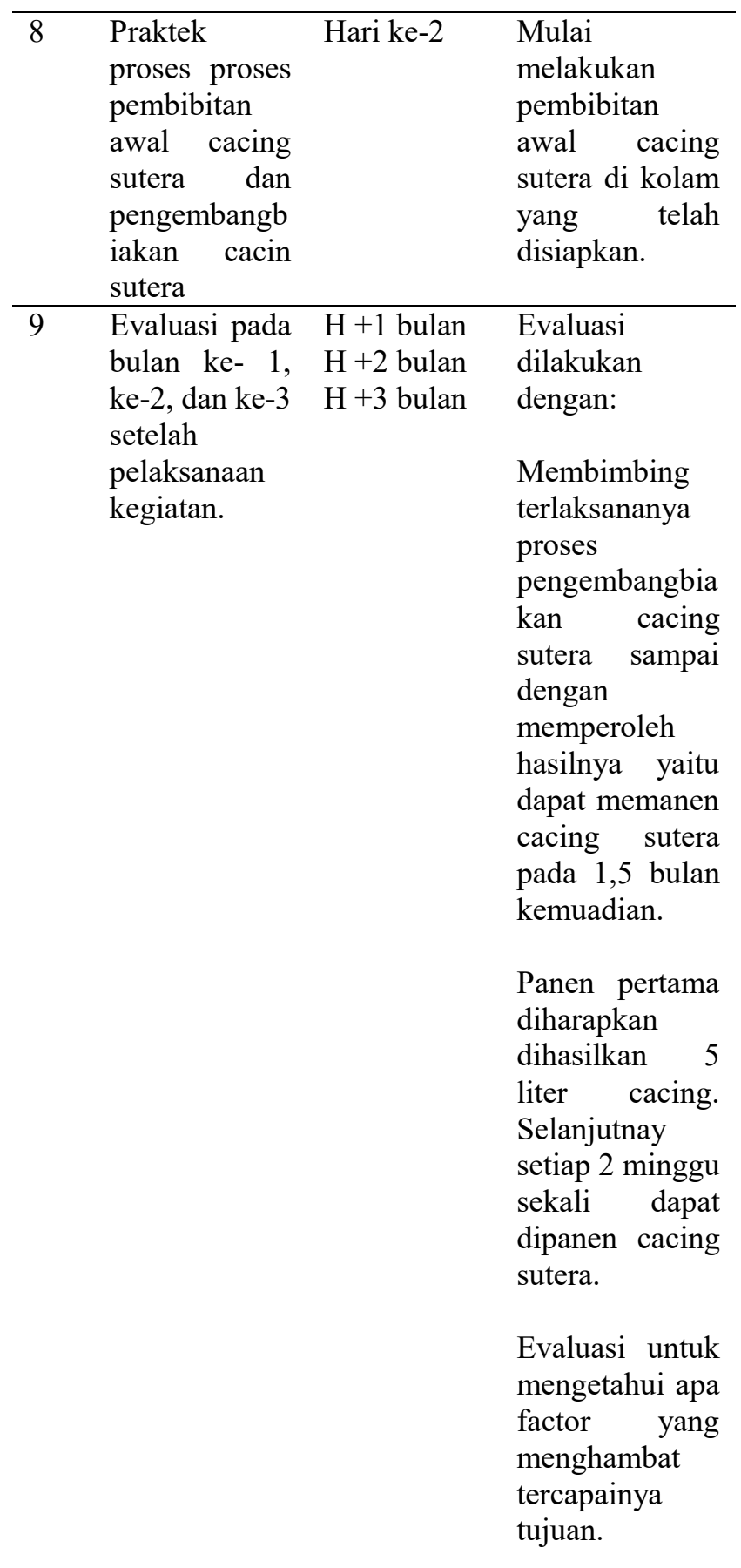

Evaluasi dilakukan setelah diadakan pelatihan. Evaluasi dengan memberikan beberapa pertanyaan untuk dijawab peserta pelatihan, untuk mengetahui sejauhmana peningkatan pemahaman dan pengetahuan peserta terhadap penyuluhan dan pelatihan yang sudah diberikan. Keberlanjutan program, dilakukan dengan melakukan evaluasi dari satu sampai dengan beberapa bulan setelah berlangsungnya kegiatan pengabdian. 


\section{Hasil dan Pembahasan}

Kegiatan pengabdian kepada masyarakat ini dilaksanakan pada hari Kamis, 28 Agustus 2020, bertempat di Desa Fajar Baru, Kecamatan Jati Agung, Lampung Selatan. Peserta adalah bapakbapak Kelompok Tani, Ketua pelaksana dan anggota pelaksana Pengabdian Kepada Masyarakat dari UNILA, dibantu beberapa mahasiswa S2 Magister Ilmu Akuntansi FEB UNILA, bertempat di rumah dan pekarangan pak Sabar, salah satu warga Kelompok Tani.

Tahapan kegiatan sebagai berikut:

1. Membuat kolam terpal dan menyiapkan sarana prasarana yang akan digunakan sebagai tempat berkembang biak cacing sutera. Kolam dibuat di pekarangan pak Sabar, salah satu warga kelompok tani. Kegiatan ini dilakukan 1 bulan sebelum dilaksanakannya kegiata pelatihan. Kolam sebanyak 2 buah, masing-masing berukuran 2 × 6 meter.

2. Pembukaan oleh Ketua Pengabdian dan Ketua Kelompok Tani.

3. Pree Test. Panitia memberikan kuesioner sebagai pre tes untuk mengetahui pengetahuan peserta sebelum diberikan pelatihan.

4. Penyuluhan tentang manfaat budidaya cacing sutera. Pemberian pengetahuan tentang seluk beluk pemasaran cacing sutera.

5. Evaluasi hasil (post test)

Berdasarkan hasil post test, terdapat peningkatan pemahaman petani setelah memperoleh penyuluhan dan pelatihan budidaya cacing sutera.

6. Praktek proses pembibitan awal cacing sutera dan pengembangbiakan cacin sutera. Mulai melakukan pembibitan awal cacing sutera di kolam yang telah disiapkan.

7. Evaluasi pada bulan ke- 1, ke-2, dan ke-3 setelah pelaksanaan kegiatan. Evaluasi dilakukan dengan:

Membimbing terlaksananya proses pengembangbiakan cacing sutera sampai dengan memperoleh hasilnya yaitu dapat memanen cacing sutera pada 1,5 bulan kemuadian dari awal pembibitan.. Panen pertama diharapkan dihasilkan 5 liter cacing. Selanjutnya setiap 2 minggu sekali dapat dipanen cacing sutera. Selain itu evaluasi juga dilakukan untuk mengetahui apa factor yang menghambat tercapainya tujuan.
8. Target keuntungan yang diharapkan dapat diperoleh:

Harga cacing sutera di pasaran dapat terjual Rp 65.000 per kilogram.

Pada penen pertama dapat menghasilkan 5 liter cacing sutera $x \operatorname{Rp} 65.000=\operatorname{Rp} 325.000$.

Panen selanjutnya dapat dilakukan 2 minggu sekali sebanyak 5 liter. Sehingga setiap bulan dapat dihasilkan 10 liter $\mathrm{x} \operatorname{Rp} 65.000=\mathrm{Rp}$ 650.000 .

9. Diharapkan kegiatan budidaya ini dapat diikuti banyak warga dengan membuat kolam terpal di pekarangan rumah masing-masing sehingga warga dapat memperoleh penghasilan tambahan yang cukup lumayan dari pekarangannya masing-masing.

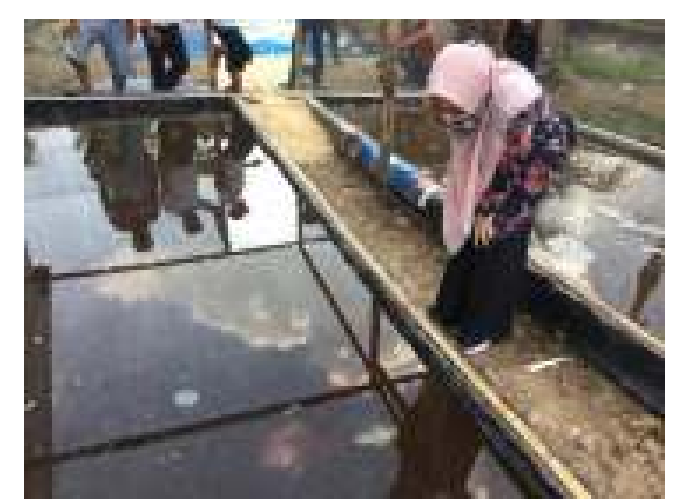

Gambar 1. Pembuatan kolam terpal sebagai tempat beternak cacing sutera

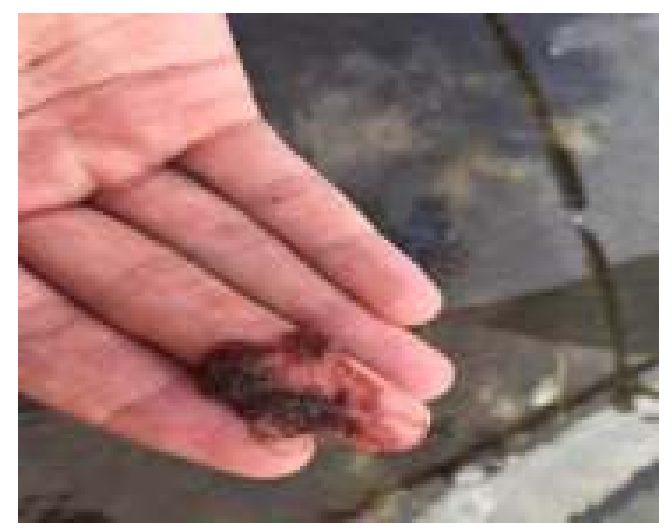

Gambar 2. Bibit cacing sutera yang akan dimasukkan ke kolam terpal untuk dikembangbiakkan 


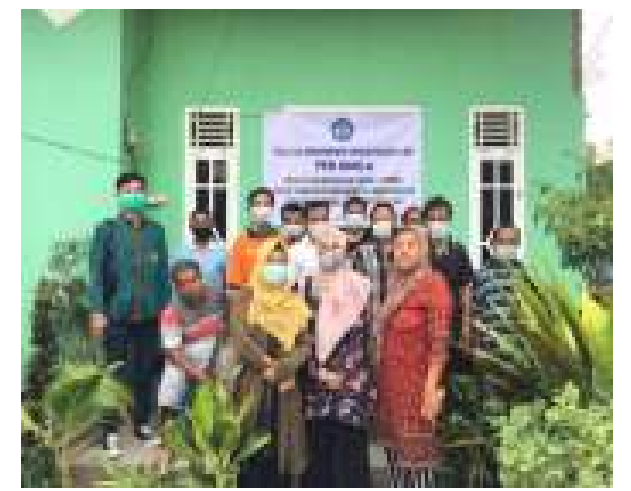

Gambar 3. Ketua Pelaksana dan anggota

Pengabdian Kepada Masyarakat, mahasiswa, Penyuluh, serta Ketua dan anggota Kelompok Tani.

\section{Kesimpulan}

Setelah kegiatan pengabdian kepada masyarakat bagi kelompok tani di Desa Fajar Baru yang dilakukan dengan memberi pelatihan dan pendampingan budidaya cacing sutera, diharapkan cacing sutera dapat berkembang biak dengan baik sesuai target sehingga petani dapat memanen cacing sutera. Panen pertama diharapkan 1,5 bulan sejak awal pembibitan. Selanjutnya diharapkan cacing sutera dapat dipanen secara rutin setiap 2 minggu sekali sehingga dapat menambah penghasilan warga.

Kegiatan budidaya ini diharapkan dapat diikuti banyak warga dengan membuat kolam terpal di pekarangan rumah masing-masing sehingga warga dapat memperoleh penghasilan tambahan yang cukup lumayan dari pekarangannya masingmasing. Dengan semakin banyaknya warga yang memiliki usaha ini di rumah masing-masing, desa ini diharapkan bisa menjadi pusat sentra budidaya cacing sutera yang menjual cacinng sutera atau dapat memenuhi kebutuhan cacing sutera untuk wilayah Lampung dan sekitarnya, dimana sebelumnya untuk produksi cacing sutera belum bisa terpenuhi dari Lampung, karena masih sedikit usaha cacing sutera ini dilakukan di lampung.

Berdasarkan hasil evaluasi yang dilakukan oleh tim, kelompok tani mengharapkan adanya pendampingan berkelanjutan untuk meningkatkan produksi cacing sutera dan membantu pemasarannya.

\section{Ucapan Terima Kasih}

Terima kasih disampaikan kepada LPPM UNILA yang telah mendanai pengabdian ini melalui hibah DIPA Unggulan Unila Tahun Anggaran 2020.

\section{Daftar Pustaka}

Fahri, LN. (2017). Pengaruh Pelaksanaan Kebijakan Dana Desa Terhadap Manajemen Keuangan Desa dalam Meningkatkan Efektivitas Program Pembangunan Desa. Jurnal Publik. 11(01): 75-88.

Gamayuni, Rindu Rika. (2017). Penguatan teknologi informasi akuntansi manajemen desa dan implementasi undang-undang No. 6 / 2014 tentang Desa untuk meningkatkan pengelolaan keuangan desa di kabupaten / kota di Lampung. Penelitian Unggulan UNILA. 